\title{
Produksi dan Kualitas Telur Itik Alabio di Daerah Sentra Peternakan Desa Sungai Pandan, Kabupaten Hulu Sungai Utara, Kalimantan Selatan
}

\author{
Production and Quality of Alabio Duck Eggs in The Livestock Center Area of Sungai \\ Pandan Village, Hulu Sungai Utara Regency, South Kalimantan
}

\author{
Rini Fajarwati ${ }^{1 *}$, Sarmanu$^{2}$, Chairul Anwar Nidom², Sri Pantja Madyawati², Imam \\ Mustofa $^{2}$, Mirni Lamid ${ }^{2}$, Sri Hidanah², Widya Paramita², Tarzan Purnomo², \\ Mohammad Sukmanadi ${ }^{2}$ \\ ${ }^{1}$ Dinas Perkebunan dan Peternakan, Provinsi Kalimantan Selatan, \\ ${ }^{2}$ Fakultas Kedokteran Hewan, Universitas Airlangga, Surabaya \\ *Corresponding author: rini.fajarwati-2015@fkh.unair.ac.id
}

\begin{abstract}
Abstrak
Penelitian ini merupakan penelitian deskriptif dengan menggunakan 20 itik Alabio betina siap bertelur dengan rentang usia 6 bulan dan untuk pemeriksaan kualitas telur untuk masing-masing kelompok 10 sampel. Pengamatan tingkat produksi telur dilakukan selama tiga bulan dengan 10 pengulangan, kualitas telur (ketebalan kulit telur, persentase kulit telur, persentase kulit telur, persentase albumin, persentase kuning telur, huagh unit, warna kuning telur, kadar protein dan lemak kandungan). Data produksi telur dan kualitas telur diuji menggunakan uji Anova. Hasil pengamatan rata-rata produksi harian telur $15.45 \pm 0.12,14.72 \pm 0.10,14.91 \pm$ 0.09; produksi berat harian (kg/hari) $925.27 \pm 7.50,875.40 \pm 6.32,884 \pm 5.03$; hasil dari ketebalan kulit telur kualitas $0.33 \pm 0.01,0.33 \pm 0.12,0.33 \pm 0.12$; persentase kulit telur $11.32 \pm 0.93,11.28 \pm 0.10,11.36 \pm 0.05$; persentase albumin $55.70 \pm 1.08,56.66 \pm 1.22$, $56.12 \pm 1.00$; persen kuning telur $32.07 \pm 1.24,31.55 \pm 1.48$, $31.64 \pm 1.20$; Haugh unit 88.70 $\pm 6.21,91.41 \pm 6.70,94.51 \pm 5.06$. Warna kuning masing-masing memiliki skor 15. Dapat disimpulkan bahwa produksi dan kualitas telur itik Alabio baik.
\end{abstract}

Kata kunci: itik Alabio, produksi, kualitas telur

\begin{abstract}
This research was a descriptive study used 20 female Alabio ducks in laying phase and 10 egg quality samples, respectively. Observation of egg production level was carried out for three months with 10 replication, egg quality (eggshell thickness, eggshell percentage, albumin percentage, egg yolk percentage, haugh unit, yolk color, protein content and fat content). Data of egg production and egg quality analysed using Anova test. The results showed that of the average daily production of eggs $15.45 \pm 0.12,14.72 \pm 0.10,14.91 \pm 0.09$; daily weight production ( $\mathrm{kg} /$ day) were $925.27 \pm 7.50,875.40 \pm 6.32,884 \pm 5.03$. The results of egg quality eggshell were thickness $0.33 \pm 0.01,0.33 \pm 0.12,0.33 \pm 0.12$; the percentage of eggshell 11.32 $\pm 0.93,11.28 \pm 0.10$, $11.36 \pm 0.05$; percentage of albumin were $55.70 \pm 1.08$; $56.66 \pm 1.22$, $56.12 \pm 1.00$; percent of egg yolk were $32.07 \pm 1.24,31.55 \pm 1.48,31.64 \pm 1.20$; haugh units were $88.70 \pm 6.21,91.41 \pm 6.70,94.51 \pm 5.06$. The yolk has a score of 15. In conclusion, the egg production and quality of Alabio duck was in good performance.
\end{abstract}

Keywords: Alabio duck, production, egg quality

Received: 2 Januari 2020

Revised: 10 Februari 2020

Accepted: 21 Februari 2020

\section{PENDAHULUAN}

Itik adalah unggas air yang banyak dibudidayakan di Indonesia. Peran itik Alabio sebagai sumber penunjang protein hewani dan dapat meningkatkan perekonomian masyarakat melalui bidang peternakan. Itik Alabio memiliki peran yang sangat besar terhadap peningkatan pendapatan peternak itik di pedesaan. Pemerintah Provinsi Kalimantan Selatan terus berupaya mengembangkan dan menjaga kelestarian itik Alabio (Suryana, 2013). 
Permana dkk. (2014), mengatakan bahwa penimgkatan ekonomi dan kesadaran masyarakat tentang kebutuhan protein hewani mengakibatkan peningkatan kebutuhan telur dan daging. Salah satu upaya untuk memenuhi kebutuhan protein hewani pada masyarakat adalah usaha peternakan. Pemanfaatan telur itik sebagai bahan pangan tidak hanya dikonsumsi langsung tetapi juga digunakan dalam berbagai produk olahan, misalnya kue dan telur asin. Berdasarkan data statistik di Provinsi Kalimantan Selatan bidang peternakan dan kesehatan konsumsi telur itik mengalami peningkatan dari tahun 2017 yang semula 23.991 ton meningkat di tahun 2018 menjadi 25.029 ton.

Pengembangan peternakan di Kalimantan Selatan khususnya di Kabupaten Hulu Sungai Utara diarahkan dari peternakan tradisional menuju peternakan yang lebih maju dengan memanfaatkan teknologi yang sedang berkembang dan meningkatkan pengetahuan para peternak itik untuk mengembangkan usahanya. Subagja et al. (2017) menjelaskan bahwa menjalankan usaha peternakan yang berkaitan dengan produksi, dihadapkan dengan beberapa masalah atau resiko usaha seperti resiko gagal produksi disebabkan oleh faktorfaktor produksi dan harga jual telur dipasar. Peternak sering mengabaikan dan tidak memahami pengetahuan tentang faktor-faktor produksi usaha ternak sehingga hasil usaha kurang maksimal (Rozi dkk., 2020).

Sulaiman dan Rahmatullah (2011), menyatakan bahwa secara umum telur itik Alabio sangat populer terutama bagi masyarakat Kalimantan Selatan, yang lebih menghargai telur itik dibanding telur ayam ras. Telur itik Alabio diklasifikasikan sebagai telur itik tambak dan telur itik pantai yang dibedakan berdasarkan besar dan derajat kuning telur (yolk), dimana telur itik tambak berukuran lebih besar dan yolk kuning kemerah-merahan. Faktor-faktor yang menentukan produksi telur adalah genetik, nutrisi, usia produksi, jenis kandang, sistem pemeliharaan (ekstensif, semi intensif, dan intensif), dan temperature. Kualitas kerabang dan kualitas internal telur yakni indeks putih telur, indeks yolk dan haugh Unit (HU) ditentukan oleh faktor- faktor seperti penyimpanan, strain unggas, umur, molting, nutrisi pakan dan penyakit (Sulaiman dan Rahmatullah, 2011).

\section{METODE PENELITIAN}

Penelitian dilaksanakan selama tiga bulan mulai dari bulan Februari hingga bulan April tahun 2018. Lokasi penelitian di Desa Putat Atas dan Hambuku Raya Kecamatan Sungai Pandan, Kabupaten Hulu Sungai Utara, Provinsi Kalimantan Selatan. Pengujian kualitas kimia telur itik Alabio dilakukan di laboratoriun pascapanen Fakultas Pertanian dan Peternakan Universitas Lambung Mangkurat.

Penelitian terdiri dari dua tahap, yakni tahap yang pertama adalah mengukur tingkat produksi telur itik Alabio dan tahap kedua adalah pemeriksaan kualitas telur itik Alabio. Metode penelitian tahap pertama adalah metode pengambilan data recording produksi telur dan tahap dua pemeriksaan kualitas telur itik Alabio. Jumlah sampel tingkat produksi telur sebanyak 600 ekor itik Alabio betina dibagi menjadi 3 kelompok, sehingga masing-masing kelompok memiliki jumlah sampel sebanyak 200 ekor itik Alabio betina. Metode tahap kedua adalah metode pemeriksaan kualitas telur, jumlah sampel tahap kedua sebesar 10 butir telur itik Alabio masing-masing kelompok.

Variable yang dikendalikan adalah umur itik, asal bibit itik, jumlah dan jenis pakan yang diberikan, serta keterampilan peternak. Variabel yang diamati adalah tingkat produksi telur dan kualitas telur itik Alabio meliputi ketebalan kerabang, persentase kerabang telur, persentase putih telur (albumin) persentase yolk, $\mathrm{Hu}$, dan uji kimia (kadar protein dan kadar lemak).

Produksi telur yang diukur adalah henday production yaitu jumlah telur berdasarkan cacatan produksi selama satu bulan dibagi dengan jumlah itik betina dikalikan seratus persen. Pengukuran berat telur dilakukan dengan menggunakan timbangan analitik, persentase berat kerabang telur, yolk, dan putih telur diperoleh dengan cara melakukan penimbangan pada kerabang telur, yolk, dan berat putih telur, sedangkan warna yolk diukur menggunakan yolk 
colour fan. Cara pengukuran dilakukan dengan pencocokan warna yolk dengan warna pada yolk colour fan.

Tebal Kerabang diukur menggunakan Mikrometer yang diambil dari tiga bagian, yaitu bagian ujung lancip kerabang telur, bagian tengah kerabang telur dan bagian ujung tumpul kerabang telur kemudian hasil dari ketiga bagian tersebut diambil nilai rata-rata. Nilai $H U$ merupakan indeks dari tinggi putih telur kental terhadap berat telur. Perubahan kualitas putih telur kental ini jalannya logaritmis dengan perubahan putih telur kental. Penghitungan nilai HU menggunakan rumus Haryanto dkk. (2019). $\mathrm{HU}=100 \log \left(\mathrm{H}+7.57-1.7 \mathrm{~W}^{0.37}\right), \mathrm{H}$ adalah tinggi albumin kental (mm), dan $\mathrm{W}$ adalah berat telur (g).

Pengujian produksi telur dan kualitas telur menggunakan analysis of variance (Anova), jika signifikan $(\mathrm{p}<0.05)$ dilanjutkan dengan LSD. Jika data tidak normal maka di gunakan uji Kruskal Wallis, jika signifikan $(\mathrm{p}<0.05)$ dilanjutkan dengan uji Mann-Whitney.

\section{HASIL DAN PEMBAHASAN}

\section{Tingkat Produksi Telur}

Hasil pengamatan tingkat produksi telur itik Alabio pada tiga kelompok petani ternak di Kecamatan Sungai Pandan menunjukkan bahwa produksi telur itik Alabio yang memiliki tingkat produksi tinggi pada Desa Putat Atas Hasil keseluruhan persentase produksi telur itik Alabio selama tiga bulan dapat dilihat pada Tabel 1 .

Hasil pengamatan tingkat produksi telur menunjukkan ada perbedaan yang nyata, hal ini dapat diduga adanya tingkat stress yang berbeda antara individu satu dengan yang lainnya, sehingga dapat mempengaruhi tingkat produksi telur. Hal tersebut diatas sesuai dengan pendapat (Huzla, 2018) tingkat stress itik berdampak pada produksi telur. Solihat dkk. (2003) menyatakan bahwa produksi telur dipengaruhi oleh pakan, genetik dan kecepatan masak kelamin.

\section{Kualitas Telur}

Hasil analisis kualitas telur ketebalan kerabang telur kandungan kalsium dan fosfor yang relatif sama pada ransum itik tidak memberikan pengaruh berbeda terhadap ketebalan kerabang. Hasil penelitian menunjukkan ketebalan kerabang telur itik Alabio memiliki rata $0.33 \pm 0.01 \mathrm{~mm}$ (Tabel 1).

Hasil tersebut sedikit lebih rendah dibandingkan dengan pendapat Nugraha et al. (2013) menyatakan bahwa tebal kerabang telur itik Magelang pada pemeliharaan secara terkurung kering adalah $0.34 \pm 0.04 \mathrm{~mm}$. Ketebalan kerabang dipengaruhi oleh asupan pakan yang mengandung kalsium dan fosfor. Hasil ketebalan kerabang telur itik Alabio ini salah satunya dipengaruhi oleh pakan yang diberikan. Pemberian ikan kering dan keong ke dalam ransum pakan dapat berpengaruh terhadap ketebalan telur, karena ikan kering dan keong merupakan sebagai salah satu sumber penghasil calsium dan phospor. Kandungan calsium dan phosphor pada ikan kering adalah 5.3\% dan $0.69 \%$. Semakin tinggi kandungan kalsium pada pakan yang terserap maka semakin baik kualitas kerabang yang dihasilkan (Ratnasari, 2016).

Berdasarkan hasil analisis statistik persentase albumin (putih telur) diperoleh bahwa antar kelompok tidak menunjukan perbedaan nyata terhadap persentase indeks albumin. Hasil persentase albumin itik Alabio pada penelitian ini memiliki rataan $55.67 \pm 1.08$, hasil ini lebih tinggi dibandingkan dengan penelitian Darmawan dkk. (2016) dalam hal peningkatann persentase berat putih telur. Hal ini kemungkinan disebabkan oleh pengaruh lemak yang terkandung didalam pakan yang diberikan.

Hasil penelitian persentase yolk itik Alabio memiliki rataan sebesar $32.07 \pm 1.24$, hasil antara kelompok atau lokasi tidak terdapat perbedaan, hal ini dikarenakan dalam penelitian ini tidak memberikan perlakuan ransum pakan antar kelompok. Kandungan protein masingmasing ransum perlakuan relatif dan mengakibatkan nilai indeks yolk yang dihasilkan relatif sama. Perhitungan persentase berat yolk relatif sama dengan pendapat (Ratnasari, 2016) yang menyatakan persentase yolk $\pm 32 \%$. Angka yang lebih tinggi dikemukakan oleh Ratnasari (2016), bahwa persentase bobot yolk mencapai $34.3 \pm 2.2 \%$. 
Tabel 1. Hasil produksi telur dan pengujian kualitas telur

\begin{tabular}{|c|c|c|c|c|c|}
\hline \multirow{2}{*}{ No } & \multirow{2}{*}{ Variabel } & \multirow{2}{*}{$\mathbf{N}$} & \multicolumn{3}{|c|}{ Kelompok } \\
\hline & & & PA & HR 1 & HR 2 \\
\hline \multirow[t]{3}{*}{1} & Tingkat Produksi Telur & & & & \\
\hline & Butir/hari/flok & 20 & $15.45^{\mathrm{a}} \pm 0.12$ & $14.72^{\mathrm{b}} \pm 0.10$ & $14.91^{\mathrm{c}} \pm 0.09$ \\
\hline & Gram/hari (g) & 200 & $925.27^{\mathrm{a}} \pm 7.50$ & $875.40^{\mathrm{b}} \pm 6.32$ & $884.13^{c} \pm 5.03$ \\
\hline \multirow[t]{7}{*}{2} & Kualitas Telur & & & & \\
\hline & Ketebalan keraban & 10 & $0.33 \pm 0.01$ & $0.33 \pm 0.12$ & $0.33 \pm 0.12$ \\
\hline & Persentase kerabang telur (\%) & 10 & $11.32 \pm 0.93$ & $11.28 \pm 0.10$ & $11.36 \pm 0.05$ \\
\hline & Persentase albumin (\%) & 10 & $55.70 \pm 1.08$ & $56.66 \pm 1.22$ & $56.12 \pm 1.00$ \\
\hline & Persentase yolk $(\%)$ & 10 & $32.07 \pm 1.24$ & $31.55 \pm 1.48$ & $31.64 \pm 1.20$ \\
\hline & $\mathrm{HU}$ & 10 & $88.70 \pm 6.21$ & $91.41 \pm 6.70$ & $94.51 \pm 5.06$ \\
\hline & Warna yolk (skor) & 10 & 15 & 15 & 15 \\
\hline
\end{tabular}

Keterangan: PA (Putat Atas), HR 1 (Hambuku Raya 1), HR 2 (Hambuku Raya 2).

Nilai rata-rata pada baris sama diikuti superskrip berbeda nyata $(\mathrm{p}<0.05)$

Nilai HU merupakan salah satu kriteria untuk menentukan kualitas telur bagian dalam dengan cara mengukur tinggi albumin telur dan bobot telur. Nilai HU tinggi menunjukkan bahwa viskositas albumin semakin pekat. Albumin mengandung ovomusin yang berperan dalam pengikatan air untuk membentuk gel albumin sehingga albumin bisa kental. Albumin semakin kental jika jala-jala ovomusin dalam jumlah banyak dan kuat sehingga viskositas albumin menjadi tinggi. Semakin tinggi nilai HU maka semakin tinggi ovomusin dan semakin baik kualitas interior telur. Hasil penelitian ini menunjukkan itik Alabio memiliki HU yang baik, dan hasil ini dipertegas dengan pendapat (Purwati dkk., 2015), bahwa nilai HU telur yang baru dikeluarkan nilainya 100 , sedangkan telur dengan mutu terbaik nilainya diatas 72 dan telur busuk nilainya di bawah 50 .

Hasil pengukuran warna yolk pada penelitian ini mendapatkan skor 15 . Nilai tersebut merupakan nilai tertinggi yang tertera pada alat ukur egg yolk colour fan merk ovocolor BASF. Skor yolk yang didapatkan dalam penelitian dapat menjelaskan bahwa warna yolk itik Alabio memiliki nilai tertinggi pada alat ukur yang digunakan. Haryanto dkk. (2019), dalam penelitiannya menghasilkan warna yolk itik Tegal yang dipelihara secara intensif dan semi intensif rata-rata 4.12 dan semi intensif 10.87 , skor tersebut lebih kecil dari skor warna itik Alabio.

\section{KESIMPULAN}

Kelompok Itik Alabio memiliki performa produksi dan kualitas telur yang baik berdasarkan variabel ketebalan kulit telur, persentase kulit telur, persentase kulit telur, persentase albumin, persentase yolk, nilai HU, warna yolk, kadar protein dan lemak kandungan.

\section{UCAPAN TERIMA KASIH}

Penulis mengucapkan terima kasih kepada Dinas Perkebunan dan Peternakan, Kalimantan Selatan dan Fakultas Kedokteran Hewan, Universitas Airlangga atas fasilitas selama penelitian.

\section{DAFTAR PUSTAKA}

Darmawan, A., Sumiati, Hermana, W. 2016. Kualitas Fisik Telur Itik Magelang yang Diberi Ransum Mengandung Tepung Daun Indigofera $S p$. dan Minyak Ikan Lemuru. Departemen Ilmu Nutrisi dan Teknologi Pakan, Fakultas Peternakan IPB.

Haryanto, A.N., Sarengat, W., Sunarti, D. 2019. Kualitas Fisik Telur Itik Tegal yang Dipelihara Menggunakan Sistem Pemeliharaan Intensif dan Semi Intensif di KTT Bulusari Kabupaten Pemalang. Program Studi Peternakan, Fakultas 
Peternakan dan Pertanian, Universitas Diponegoro.

Huzla, S. 2018. Produksi Telur, Fertilitas dan Daya Tetas Telur Itik Alabio pada Rasio Jantan dan Betina Berbeda. Universitas Mataram.

Ismoyowati, Purwantini, D. 2013. Produksi dan Kualitas Telur Itik Lokal di Daerah Sentra Peternakan Itik.

Ketaren, P.P. 2007. Peran Itik Sebagai Penghasil Telur Dan Daging Nasional. Balai Penelitian Ternak Bogor, 16002.

Keynesandy. A.W. 2012. Performa Sifat Produksi dan Kualitas Telur Hasil Persilangan Resiprokal Antara Itik Alabio dengan Itik Pekin. Fakultas Peternakan. Institut Pertanian Bogor.

Laporan Dinas Perkebunan Dan Peternakan Provinsi Kalimantan Selaan Dalam Angka. 2019.

Nugraha, F.S., Mufti, M., Hari, I. 2013. Kualitas telur yang dipelihara secara terkurung basah dan kering di Kabupaten Cirebon. J. Ilmiah Pet., 1(2), 726-734.

Permana, D., Lamid, M., Mulyati, S. 2014. Perbedaan Potensi Pemberian Bahan Subtitusi Tepung Limbah Udang dan Cangkang Kepiting Terhadap Berat Telur dan Kerabang Telur Itik. Fakultas Kedokteran Hewan Universitas Airlangga.

Prasetya, F.H., Setiawan, I., Garnida, D. 2016. Karakteristik Eksterior dan Interior Telur Itik Bali (Kasus Di Kelompok Ternak Itik Maniksari Di Dusun Lepang, Desa Takmung Kec.Banjarangkan, Kab. Klungkung, Provinsi Bali). Fakultas Peternakan Universitas Padjadjaran.
Purwati, D., Djaelani, M.A., Yuniwarti, E. 2015. Indeks Kuning Telur (IKT), Haugh Unit $(H U)$ dan Bobot Telur pada Berbagai Itik Lokal di Jawa Tengah. Fakultas Sains dan Matematika Universitas Diponegoro.

Ratnasari, N.A. 2016. Kualitas Fisik Telur Itik Magelang yang diberi Pakan Mengandung Tepung Daun Indigofera Zollingeriana dan Minyak Ikan Lemuru. Fakultas Peternakan. Institut Pertanian Bogor.

Rozi, F., Rahmahani, J., Purnama, M.T.E., Hamid, I.S., Yudhana, A., Praja, R.N. 2020. Seroprevalensi Antibodi Newcastle Disease (ND) pada Itik di Desa Temuasri, Sempu, Banyuwangi. Jurnal Medik Veteriner, 3(1), 108-113.

Solihat, S., Suswoyo, Ismoyowati, I. 2003. Kemampuan Performan Produksi Telur dari Berbagai Itik Lokal. Jurnal Peternakan Tropis, 3(1), 27-32.

Subagja, H., Prasetyo, B., Nurjanah, H. 2017. Production Factor Affecting Layer Duck Bussiness of Semi-Intensive Poultry Farm in Jember Regency. Jurusan Peternakan Politeknik Negeri Jember.

Subiharta, D.M., Yuwono, P., Sudrajad. 2013. Karakteristik Itik Tegal (Anas Plantyhynchos Javanicus) sebagai Itik Petelur Unggulan Lokal Jawa Tengah dan Upaya Peningkatan Produksinya. Seminar Nasional: Menggagas Kebangkitan Komoditas Unggulan Lokal Pertanian dan Kelautan. Fakultas Pertanian Uniersitas Trimojoya: Madura.

Sulaiman, A., Rahmatullah, S.N. 2011. Karakteristik Eksterior, Produksi dan Kualitas Telur Itik Alabio (Anas plathynchos Borneo) di Sentra Peternakan Itik Kalimantan Selatan. Fakultas Pertanian Universitas Lambung Mangkurat. Kalimantan Selatan. 